\title{
"Escolas cheias, cadeias vazias"1 Nota sobre as raízes ideológicas do pensamento educacional brasileiro
}

\author{
MARIA HELENA SOUZA PATTO
}

"Hegel observa em uma de suas obras que todos os fatos e personagens de grande importância na história do mundo ocorrem, por assim dizer, duas vezes. E esqueceu de acrescentar: a primeira vez como tragédia, a segunda como farsa."

(Karl Marx, O 18 Brumário de Luís Bonaparte)

CONSCIÊNCIA da precariedade da escola oferecida às crianças das classes
populares - uma escola que, como regra, não garante mais nem mesmo
alguma capacidade de ler e escrever - tornou-se de domínio público. A cada publicação de resultados de pesquisas dos níveis de aprendizagem das matérias escolares de alunos da rede pública brasileira de ensinos Fundamental e Médio que confirmam o desastre, surgem editoriais e reportagens na mídia que denunciam o estado de coisas vigente. Usuários dessa escola, com os quais convivemos no cotidiano, referem-se com freqüência a filhos ou parentes que estão nas últimas séries do Ensino Fundamental ou mesmo no Ensino Médio e mal conseguem ler. Alunos e ex-alunos do Ensino Médio regular ou Supletivo falam do quase nada que lhes é ou foi ensinado. Entrevistados sobre o assunto, políticos e especialistas não raro responsabilizam usuários e professores.

O objetivo deste texto não é contar a história da educação no Império nem demarcar o chão econômico, social e político em que ela se faz, trabalho que já fizemos em textos já publicados (Patto, 1996 e 1999). Não é também produzir conhecimento sobre o que se passa no cotidiano das escolas públicas brasileiras, pois são inúmeras as pesquisas de várias dimensões da realidade da escola pública que vêm mostrando, nos últimos quinze ou vinte anos, o processo de produção de sua crescente precariedade como instituição de ensino e que revelam equívocos tecnicistas; desinteresse de governantes pela efetiva formação escolar da maioria das crianças e jovens brasileiros; medidas de barateamento do custo-aluno; desvalorização dos educadores sob a forma de baixos salários, formação profissional precária e imposição, por instâncias superiores, de reformas e projetos educacionais; política educacional pautada por disputas partidárias e interesses eleitoreiros que produzem repetida descontinuidade técnica e administrativa gerada pela sistemática destruição, a cada governo, do que foi feito 
pelos antecessores; conseqüências educacionais nefastas da política neoliberal e da interferência de órgãos de agiotagem internacional nos rumos da educação escolar. Em 1994, Alfredo Bosi (1996) resumiu a essência desse processo num pequeno texto exemplar. Tudo isso nos permite afirmar que, neste momento da história do país, o ensino público de Primeiro e Segundo Graus está aquém até mesmo da pseudoformação criticada por Adorno (1995), ou seja, até mesmo do ensino limitado à racionalidade instrumental. Também não trataremos das raras e efêmeras exceções a esse quadro, usualmente mencionadas para justificar um otimismo ingênuo ou impostor.

O que queremos é sublinhar a regra: a improdutividade dos ensinos Fundamental e Médio como principal produto da escola pública, há muito apontada na literatura especializada, atingiu proporções inaceitáveis. ${ }^{2}$ Nesse terreno, criam-se bolsas-família que têm como exigência a obrigatoriedade de freqüência à escola das crianças das famílias beneficiadas, não importa a qualidade do ensino oferecido, e crescem programas educativos desenvolvidos por organizações não-governamentais que não concebem a educação como direito à formação intelectual - ou seja, à informação que fundamenta a reflexão e mobiliza a práxis -, mas ensinam, em chave assistencialista e à guisa de "inclusão social", passos de capoeira, noções de algum esporte, padaria e confeitaria, arremedos de artesanato, às vezes nos próprios prédios escolares. Tais programas em geral promovem formas de "inclusão marginal", não raro de natureza perversa. ${ }^{3}$ Paralelamente cresce uma rede de empresas privadas de Ensino Superior, de ingresso fácil e de qualidade duvidosa, recentemente beneficiadas pelo governo federal por meio do Pró-Uni.

A cada crime chocante cometido por jovens destituídos de todos os direitos e vítimas da barbárie contra os pobres que atravessa a história do Brasil, contudo, o discurso dominante traz ao primeiro plano uma concepção de escola como instituição salvadora, cuja missão impossível é tirar das ruas crianças e jovens moradores nas áreas urbanas mais precárias das cidades e assim diminuir os índices de criminalidade, seja ensinando-lhes princípios de moral e bons costumes seja fornecendo-lhes um diploma ilusório que não lhes garantirá emprego em tempos de desemprego estrutural. Na propaganda eleitoral de outubro de 2006, os bordões de dois candidatos a deputado federal resumiram com precisão a alma do negócio: "uma sala de aula a mais, uma cela a menos", insistia um deles; "educar crianças para não precisar punir adultos", repetia o outro.

Como veremos, nada de novo no front das idéias educacionais hegemônicas. Assistimos à continuidade de uma crença que ganhou força sob a influência do "racismo científico" das teorias raciais oitocentistas que, como mostra Schwacz (1993), tomaram de assalto os nossos "homens de sciencia" desde o Segundo Império: com pretensão de neutralidade científica, passou-se a acreditar na inferioridade do povo brasileiro, porque negro e mestiço, pressuposto ideológico que adquiriu fôlego na Primeira República e justificou uma estrutura social hierárquica e injusta e uma política educacional coerente com essa crença. Essa tese alastrou-se por todos os espaços sociais: 
se nessas esferas institucionais é muitas vezes como um discurso culpado - e cientificamente legitimado - que o argumento racial de análise social aparece referido, o mesmo não poder ser dito de outros meios, onde esse modelo científico determinista parece ser assumido sem qualquer receio. Nos discursos do dia-a-dia, na representação popular, nos jornais de circulação diária, é quase corriqueiro o argumento que traduz a ciência em termos populares e encara a raça como uma questão de importância fundamental nos destinos da nação.

(Schwacz, 1993, p.245)

Noutras palavras, o pensamento cotidiano como locus do senso comum, tal como o define Agnes Heller (1972), foi invadido por essa crença.

A partir de então, as reformas e os projetos educacionais e o entendimento das dificuldades crônicas de escolarização que assolam grande contingente dos alunos da rede pública de ensino têm-se norteado por uma longa paráfrase de uma concepção fundamental: os pobres são menos capazes, mais ignorantes, mais propensos à delinqüência - seja por motivos constitucionais seja por deficiências no ambiente familiar, lido em chave moralista -, motivo pelo qual, no discurso oficial, uma das concepções mais pregnantes da função social da escola, ao longo da história do pensamento educacional brasileiro, é, explícita ou implicitamente, a de prevenção da criminalidade, o que praticamente anula a escola como instituição que tem o dever de garantir o direito de todos ao letramento e ao saber. ${ }^{4}$

Mais de cem anos depois, a continuidade desses mitos sobre o povo e sobre a função social da escola é prova impressionante da força do preconceito, que resiste ao conhecimento alcançado a respeito da complexidade dos determinantes do crime e da própria criminalização das condutas de pobres e negros como prática de natureza política. Na atual conjuntura de desemprego e de permanência da barbárie que sempre marcou a relação de classes no país, está aberta a porta à destituição da escola como instituição de ensino e à transformação dela em lugar de detenção maquiada dos filhos dos pobres e de violência sem precedentes. ${ }^{5}$

Desnecessário dizer, o Brasil do Segundo Império não é o Brasil atual, pois o processo histórico é feito de descontinuidade. Mas não só: a história é um processo de descontinuidade e de continuidade. Segundo Hobsbawm (1998a, p.47), "é tarefa dos historiadores saber consideravelmente mais sobre o passado do que as outras pessoas, e não podem ser bons historiadores a menos que tenham aprendido, com ou sem teoria, a reconhecer semelhanças e diferenças". Ora, a história oficial da educação brasileira tem sido escrita em chave evolutiva, centrada no elogio dos progressos realizados, o que dá margem a uma historiografia celebrativa e lacunar, plena de abstrações e inversões típicas do discurso ideológico, sem nenhuma atenção ao engajamento político inevitavelmente entranhado na base do conhecimento, ou seja, à relação das idéias com a realidade concreta onde são engendradas e ganham relevo. ${ }^{6}$ A ênfase no culto ao progresso escanteia o conservadorismo, o patrimonialismo, o paternalismo, o 
autoritarismo e a desigualdade de uma sociedade cuja história tem muito de dejà vu, de "velhos vinhos em novas garrafas", de permanência de uma mentalidade gerada nas condições específicas de nossa história, em que "as Constituições são feitas para não serem cumpridas, as leis existem para serem violadas" (Buarque de Holanda, 1982, p.136-7).

Dizendo de outro modo, não se pode ignorar que a história brasileira é história lenta, em que tudo muda para que tudo permaneça como está (Martins, 1999). Assim, quando qualificamos como farsa as recorrências de fatos históricos que foram trágicos no passado, estamos contemplando a continuidade, mas sobretudo a descontinuidade histórica, pois a passagem da tragédia à farsa se dá no bojo de diferenças econômicas, sociais, políticas e culturais historicamente produzidas para que se garanta a continuidade da lógica cruel que sustenta a sociedade num país capitalista de Terceiro Mundo. Ao saltar do império de Napoleão Bonaparte ao império de Luís Napoleão, Marx sabia muito bem que a França da virada do século XVIII e da segunda metade do século XIX era e não era mais a mesma.

\section{"Escolas cheias, cadeias vazias": os Pareceres de Rui Barbosa}

Muito antes dos pareceres seminais de Rui Barbosa sobre a Reforma do Ensino Primário, Secundário e Superior (1882-1883), o entendimento da escola como instituição mantenedora da ordem social já marcava presença, desde o século XVIII, na história do pensamento educacional brasileiro. A título de exemplo, mencionemos alguns momentos dessa história, sem nenhuma intenção ou possibilidade de produzir um texto de natureza historiográfica.

Homem de confiança de José I, o marquês de Pombal foi déspota esclarecido muito mais por imposição de necessidades da Coroa do que por adesão ao espírito inovador (Maxwell, 1996). Banidos os jesuítas, reformou o sistema educacional não tanto por discordar da educação oferecida pela Companhia de Jesus, mas para anular o poder que os seguidores de Inácio de Loyola exerciam no mundo secular e repor o poder absoluto da monarquia portuguesa. Dizendo de outro modo, não para pôr a educação em moldes racionalistas, mas para eliminar a ação colonizadora e mercantil da Ordem Inaciana, que contrariava os interesses da Casa de Bragança. O Alvará de 1759 - Reforma do ensino de humanidades - é feito de palavras duras contra o método de ensino jesuítico; de luzes fracas; de nostalgia forte de um período de glória que ficara para trás; de intenção ambígua de acertar o passo português com "as nações polidas da Europa" e de desejo explícito de garantir a obediência da colônia ao Estado monárquico português. ${ }^{7}$ No centro, o controle do corpo docente pelo Estado, de onde a criação do cargo de diretor de Estudos, a quem caberia "averiguar com especial exatidão o progresso dos estudos para me poder dar no fim de cada ano uma relação fiel do estado dele ao fim de evitar os abusos”. O fim último era "extirpar as controvérsias, e fazer que entre eles [os professores] haja uma perfeita paz, e uma constante uniformidade de doutrina” (Moacyr, 1936, p.16-7 - grifo meu). 
Uma "Memória" da autoria de Martim Francisco, deputado constituinte por São Paulo, acolhida pela Comissão de Instrução Pública da Assembléia Constituinte de 1823 como "verdadeiro método de ensinar" e "luminoso sistema" que deveria ser adotado em todas as províncias do Brasil”, trazia, na superfície, proposta de criação de uma base geral da instrução escolar que disseminasse pelos povos "maior massa de luzes", mas no fundo continha uma visão de escola como instrumento de submissão moral que justificava a instrução pública como instrumento do soberano para "banir a discórdia” (ibidem, p.118-9).

O próprio método Lancaster, mencionado na Fala do Trono de 1823, quando Pedro I anunciou a abertura de uma escola lancasteriana na capital do Império, era impressionante engrenagem de ensino baseada na divisão precisa do trabalho de mestres de alunos e de controle do comportamento por meio de sinos, palmas, gestos e olhares, acoplados a rígida hierarquia. Em 1835, ao retomar o projeto de D. João VI de criar uma Universidade no Brasil, um ministro do Império sublinhou a intenção: “os professores teriam maior zelo na realização de seus deveres e a subordinação dos alunos seria mais completa, as intrigas desapareceriam e não se veriam mais estas perturbações que fizeram outrora destes estabelecimentos um centro mais de dissensões do que de Luzes" (Pires de Almeida, 1889, p.122). Na "instrução das massas", a escola profissional era tida por intelectuais do Império como instituição perfeita para fechar a porta "às idéias de revolução e mudança de governo e dirigir as idéias do povo para as fontes do trabalho agrícola, industrial e comercial"; no preparo das elites, a educação para o trabalho seria recurso poderoso para distanciar os alunos de “teorias e perigosas utopias" (ibidem, p.156). Critérios de avaliação de instituições educativas deixavam claro o verdadeiro intento: a respeito do Colégio dos Educandos, internato localizado em São Luiz do Maranhão e que abrigava cerca de 150 crianças pobres, consta que "os habitantes da província dele se ufanam e dizem, com verdade, que não há nenhum caso de antigos alunos deste estabelecimento que tenham sido objeto de processo por crime ou delito" (ibidem, p.22).

À medida que o século avançava, as notícias que chegavam da Europa sobre a criação de sistemas nacionais de ensino eram resíduo diurno que começava a surgir nos sonhos das elites brasileiras. A máxima "quem não sabe escrever em linha reta, não sabe agir em linha reta" começava a encontrar espaço no imaginário dos que conduziam o Império. Numa época em que a ordem imperial e escravocrata estava prestes a desabar e movimentos migratórios internos e externos começavam a inchar os centros urbanos que se industrializavam, diminuir a criminalidade urbana passou a fazer parte do plano de metas políticas. Para atingi-la, previa-se a inibição de atos populares de rebeldia e de protesto que, criminalizados e patologizados, começavam a aumentar os índices oficiais de crime e de loucura e a causar alarde entre os que temiam ataques à propriedade privada. Seguindo a tendência européia, intelectuais e políticos brasileiros que pensavam o futuro da nação atribuíam à escola a realização dessa tarefa. Tinha 
início aqui a presença do lema "Escolas cheias, cadeias vazias", que tomará corpo entre políticos, juristas, médicos e educadores republicanos. ${ }^{8}$

No decreto de 1879 sobre a reforma do ensino, da autoria do ministro Leôncio de Carvalho, a obrigatoriedade do ensino já se justificava não só como recurso de desenvolvimento das forças produtivas, mas também de diminuição de gastos públicos com segurança pública:

toda despesa feita com a instrução do povo importa, na realidade, uma economia, porque está provado, por escrupulosos trabalhos estatísticos, que a educação, diminuindo consideravelmente o número de indigentes, de enfermos e de criminosos, aquilo que o Estado despende com as escolas poupa em maior escala com asilos, hospitais e cadeias. (Moacyr, 1936, p.183)

Para resguardar a sociedade do que via como resultado da indiferença e da negligência dos responsáveis pelas crianças, Carvalho não considerava suficiente promulgar leis reprimindo o vício e o crime; diante "do grande número de meninos abandonados à ignorância, criados em contato com todos os vícios e expostos à influência dos mais perniciosos exemplos”, ele perguntava: "o que faremos deles e, mais importante, o que farão eles de nós?". A resposta estava na educação, verdadeira questão "de defesa pessoal” (ibidem, p.182-3), instrumento político que garante o dever do governo de "proteger as pessoas e a propriedade contra o que as possa pôr em perigo. Ora, a principal causa dos perigos que arriscam a propriedade e as pessoas é a ignorância crassa do comum do povo" (ibidem, p.184-5). No ocaso do modo de produção escravocrata, a idéia, já antiga na Europa, de valer-se da escola para moralizar o povo e preparálo para o trabalho, começava a ter repercussão aqui: o texto ligava a instrução dos trabalhadores à promoção da ordem social e do desenvolvimento econômico da nação. Nas palavras do ministro Leôncio, "moralizando o povo, inspirando-lhe o hábito e o amor ao trabalho", a instrução "desenvolve todos os ramos da indústria, aumenta a produção e com esta a riqueza pública e as rendas do Estado”.

O declínio monárquico e a radicalização republicana dividiram o Partido Liberal em duas facções que discordavam quanto à participação popular no processo político: os "revolucionários", favoráveis à ampla participação social na vida política, e os "evolucionistas", que desejavam uma transição sem traumas - isto é, sem povo. Estes últimos tinham à frente o positivista Benjamin Constant e punham a ordem e o progresso em íntima relação. Entre eles, estava o parlamentar Rui Barbosa, que, na noite de 11 de novembro de 1889, dirigiu-se à casa do marechal Deodoro para a reunião conspiradora que fez cair o Trono.

Rui Barbosa foi autor do primeiro projeto de reforma geral da educação escolar nacional fundado em tratamento sistematizado das questões do ensino segundo a última palavra dos "competentes", que era como ele próprio nomeava políticos e intelectuais europeus e norte-americanos de prestígio no campo educacional. O caso é extraordinário: no exercício da função de relator da Comissão de Instrução Pública da Câmara dos Deputados, o então deputado pela Bahia apresentou ao Parlamento, em 1882, parecer ao projeto do minis- 
tro Leôncio de Carvalho. Muito mais do que simples avaliação dos termos do decreto, o parecer foi proposta substitutiva de mais de 1.500 páginas, divididas em dois pareceres, que expõem os fundamentos teóricos e práticos de um novo projeto de reforma do Ensino Primário, Secundário e Superior. Uma atividade parlamentar rotineira que, como regra, limitava-se a textos curtos e retóricos, assumiu proporções inéditas. ${ }^{9} \mathrm{O}$ desejo confesso desse brasileiro fascinado pela Europa e pelos Estados Unidos era pôr a educação brasileira "no rumo científico e liberal do nosso tempo" (Barbosa, 1947, X(IV), p.67). Não trataremos do conteúdo propriamente pedagógico do projeto, nem de sua influência sobre o projeto educacional primeiro-republicano; o que queremos é assinalar aspectos da contribuição de Barbosa à construção de concepções ideológicas a respeito da escola pública e de sua clientela, especialmente do papel atribuído a essa instituição social no controle da criminalidade, à medida que os negros iam sendo libertos e começava a política de imigração.

Em meio a uma profusão disparatada de notáveis e de ilustres desconhecidos de todos os tempos, seis intelectuais conservadores lastreiam a proposta: Fichte, Comte, Littré, Spencer, Thomas Huxley e Horace Mann, representantes das idéias então dominantes na Alemanha, na França, na Inglaterra e nos Estados Unidos, países que Rui Barbosa admirava. ${ }^{10} \mathrm{O}$ ideário político de fundo traz a marca da ambigüidade: enquanto algumas passagens põem em destaque princípios liberais, outras seguem de perto os cânones da filosofia positiva. Entre uma posição e outra, Rui não esconde a simpatia pela segunda: "o positivismo, longe de ser uma seita estéril, ou um catecismo de fórmulas abstratas, poderia bem alimentar as privações aos foros de uma vasta filosofia da realidade, útil aos homens de governo como aos homens de ciência” (Barbosa, 1947, X(IV), p.95).

Quando predomina a veia liberal, ele defende a legitimidade do ensino de todas as teorias políticas, de todos os sistemas de organização social, e chega ao ponto de assinar embaixo da opinião de um político belga de que a escola particular pode ensinar até mesmo o desprezo da lei (ibidem, X(II), p.31). Contrário ao princípio de que "as crianças pertencem à república, antes de pertencerem aos pais", Rui rejeita "esse detestável erro, que promove o Estado ao papel de Mentor do espírito humano e pai dos pais de famílias” e lhe dá o status inaceitável de "pontífice ultra-divino" (ibidem, p.7). No entanto, quando dominam os princípios positivistas, ele quer a presença forte do Estado na educação escolar e defende o princípio positivista de que o progresso não se faz por iniciativa da sociedade inteira, mas deve ser organizado por uma só mão - a dos dirigentes do Estado positivo (ibidem, X(I), p.97). Para conciliar essas duas posições, vai buscar em Stuart Mill, que discutiu a questão da educação à luz da lei de mercado liberal, a seguinte passagem de Principles of political economy:

Gente inculta não pode avaliar o preço da cultura da alma [...] Qualquer governo um pouco civilizado e de boas intenções pode, sem presunção, acreditar-se provido de uma instrução superior à média da sociedade governada, e ter-se por capaz de oferecer uma educação e um ensino melhores do que o povo, 
entregue a si mesmo, reclamaria. É, portanto, a educação uma das coisas que, podemo-lo admitir como princípio, o governo deve distribuir ao povo. Ela constitui um dos casos a que não se aplicam necessariamente os motivos da regra da nãointervenção. (ibidem, p. 106-7 - grifo no original)

Assim sendo, ao insistir nos pareceres que a Comissão de Ensino da Câmara tomasse medidas para a criação de um Ministério de Instrução Pública, o parecerista não tinha em mente garantir a educação escolar como um direito do cidadão e um dever do Estado, mas como um direito do Estado de impedir a ignorância e suas nefastas conseqüências sociais e um dever dos pais de garantir a presença dos filhos nos bancos escolares.

Rui participava do mito da escola redentora: à “ignorância popular, mãe da servilidade e da miséria, formidável inimigo, o inimigo intestino que se asila nas entranhas do país" (ibidem, p.121-2), ele contrapunha a escola como "o alfa e o ômega", o princípio e o fim de tudo, dotado de poder absoluto de modelagem da vida social. Nos pareceres, cabe à Escola cumprir três funções: "a educação geral do povo [...] é, na mais liberal acepção da palavra, o primeiro elemento de ordem, a mais decisiva condição de superioridade militar e a maior de todas as forças produtivas" (ibidem, p.139-40 - grifos meus). Examinemos cada uma delas, começando com a relação da escola com o poder militar e terminando com sua função mantenedora da harmonia social.

O projeto tem em vista uma educação escolar que promova a segurança e o poder nacional. Nesse aspecto, o modelo é a Alemanha, que, depois da invasão napoleônica, promovera reformas escolares profundas, sob o influxo dos discursos de Fichte à nação alemã. $\mathrm{O}$ nacionalismo bélico alemão encantou o nosso deputado. O triunfo da Prússia sobre a França em 1870 é para ele confirmação da "superioridade da instrução geral no seio da nação vencedora". As medidas educacionais tomadas pela França depois da derrota na guerra franco-prussiana são lidas na mesma chave. As necessidades do ensino estão, nos pareceres, em pé de igualdade com as de defesa nacional.

Além de promotora de poderio nacional, a educação pública é requisito do progresso econômico: "se há, com efeito, verdade econômica bem estabelecida hoje, ela está em que o país mais ilustrado é, ou há de ser, se ainda não o é, o mais rico" (ibidem, p.130). A industrialização do país é meta que justifica o investimento em educação, pois "o trabalho industrial é elemento imprescindível de civilização e de riqueza, ainda que entre os povos lavradores” (ibidem, p.178). $\mathrm{Na}$ formação do trabalhador o ensino é "agente invisível que, centuplicando a energia do braço humano, é, sem dúvida, a mais poderosa das máquinas de trabalho" (ibidem, p.179). Foi assim que Rui introduziu em território nacional uma versão incipiente do que mais tarde será a "teoria do capital humano": a educação popular é "a mais fecunda de todas as medidas financeiras [...] o que falece aos nossos financeiros em geral é este singelo rudimento da ciência das finanças” (ibidem, IX(I), p.148). No bojo dessas concepções, não podia faltar a apologia do trabalho como abstração, agravada aqui pela presença da escravidão: 
o trabalho não é o castigo; é a santificação das criaturas. Tudo o que nasce do trabalho, é bom. Tudo o que se amontoa pelo trabalho, é justo. Tudo o que se assenta no trabalho, é útil. Por isso, a riqueza, por isso o capital, que emanam do trabalho, são, como ele, providenciais; como ele, necessários; benfazejos como ele. (ibidem, X(I), p.196)

Nos pareceres, a educação escolar, no entanto, é, acima de tudo, instituição que tem por finalidade garantir a ordem social. Rui Barbosa também se perguntou: "como fazer face à crescente criminalidade urbana? $\mathrm{O}$ que fazer com os degradados que vão surgir da senzala para a liberdade? Como conservar-lhes a força de trabalho que a emancipação poderá esmorecer?". A resposta está no ensino, que disciplina a plebe e a capacita para o trabalho (ibidem, p.179). Daí a máxima que, mutatis mutandis, estava na boca de políticos e homens de ciência, aqui e no exterior: "o dinheiro gasto com escolas é outro tanto economizado em prisões" (ibidem, p.186). O entendimento da escola como antídoto da desordem pública vinha dos Estados Unidos, a "grande república do norte", onde políticos e intelectuais vaticinavam a tragédia da anarquia social que líderes despóticos podiam instalar no vazio da educação popular. Para eles, evitar a ruína da república é missão do mestre-escola.

Uma concepção de progresso como evolução social gradual e natural - avessa, portanto, a qualquer ruptura produzida artificialmente pelos homens - condenava os ritmos sociais não-domesticados. Rui estava em sintonia perfeita com o conservadorismo político do positivismo comteano: todo e qualquer ideário que pregasse mudança no curso natural da evolução social era "filosofia vã", de efeitos desordeiros, que convinha extirpar por meio da educação moral. Portador do ideal positivista de progresso ordeiro, o parlamentar brasileiro redigiu uma passagem do parecer que bem poderia ter saído da pena de Comte: em defesa das instituições sociais comprometidas com o "progresso calmo", ele enaltece os governos cujo interesse é

evitar a revolução, favorecendo a evolução; arredar as catástrofes, promovendo as reformas; acautelar a sociedade contra as subversões, apoiando as mudanças graduais. Para estas instituições, a educação popular não é perigo, nem ameaça, nem incômodo; é, ao contrário, uma condição da vida normal, de segurança, de desenvolvimento tranqüilo. (ibidem, p.141)

Aos problemas sociais que a dissolução da ordem imperial desenhava na cena urbana ele contrapunha a educação, à qual caberia temperar os homens para as agruras da pobreza por meio da crença na redenção pelo trabalho. Essa mesma leitura da função social da escola estará entre os educadores da Primeira República, assombrados pelo fantasma dos movimentos sociais, então chamados “questão social”, que para alguns era um "caso de polícia” e para outros, um "caso de educação escolar".

Nessa segunda direção, os próprios objetivos das matérias escolares são também definidos por Barbosa em termos conservadores. A música e o canto, por exemplo, valem muito menos pela experiência estética do que pelo fato 
de "desenvolver os vários órgãos do ouvido e da palavra, adoçar os costumes, civilizar as classes inferiores, aligeirar para elas as fadigas do trabalho e proporcionar-lhes um inocente prazer, em vez de distrações muitas vezes grosseiras e arruinadoras" (ibidem, X(II), p.103). O ensino da História não escapa do objetivo de "adoçar o povo", o que requer que se evite contá-la a partir das paixões que a movem e que estão, segundo Rui, na origem do crime e das ações políticas revolucionárias (ibidem, p.344).

Para definir o objetivo do ensino da Economia Política - "o estudo da riqueza, sua produção, sua distribuição, seu caráter” -, ele faz suas as palavras do biólogo e pensador inglês Thomas Huxley, que afirma que ele só vale se evitar o conflito entre o capital e o trabalho; se incutir nas "partes menos afortunadas e mais duramente laboriosas da nação [...] a convicção do caráter providencial das desigualdades"; se apagar "a chama sinistra das paixões niveladoras"; se produzir o "bom-senso contra as loucuras socialistas, contra os ódios inspiradores da subversão revolucionária” (ibidem, p.361-2). A moral, por seu turno, deve ser científica, de modo a afastar crendices e superstições. Só assim é possível ensinar a "esperar o infortúnio ou a prosperidade como conseqüências naturais da nossa obediência às condições necessárias da nossa vida” (ibidem, p.373). Por isso, a instrução moral destina-se a

inculcar aos meninos o amor ao dever, a idéia de trabalho, da atividade, da frugalidade, do bom emprego do tempo, da probidade, da sinceridade absoluta, do self-control, do acatamento dos direitos do próximo, da obediência devida à lei, da decência, da morigeração, da pureza e polidez da linguagem, da lealdade, da caridade, do amor da pátria. (ibidem, p.372)

O autocontrole (a "vontade", nos termos de uma psicologia das faculdades, então ainda em vigor) é condição de autogoverno, ou seja, esse só será possível depois que o povo internalizar as regras morais que harmonizam as relações sociais. Valendo-se outra vez de Huxley, Rui Barbosa adverte que, sem a garantia da moralidade, ensinar a ler e a escrever é convite à desobediência civil: "se me impuserem a alternativa, antes quereria que os filhos das classes pobres se criassem na ignorância dessas duas prestimosas artes, do que serem alheios a esse conhecimento da sabedoria e da virtude, para o qual são apenas meios a escrita e a leitura" (ibidem, p.366-7). O biólogo inglês sabia o que estava dizendo ao fazer a advertência que Rui Barbosa entendeu tão bem: todo cuidado é pouco quando se trata de oferecer aos explorados chaves que possam dar acesso à consciência crítica. Por isso, o parecerista acautelava o imperador dos perigos da liberdade do ensino: "o meu conselho seria que não proclamasse a liberdade sem limites do ensino; que não se abstivesse de todo no que interessa à instrução pública, a menos que o mundo adiantasse um imenso passo na vereda do progresso" (ibidem, X(I), p.96).

Mais do que no conteúdo das matérias, a intenção de controle social absoluto encontrou, nesse projeto, expressão perfeita nas prescrições médicas da Higiene Escolar. São mais de sessenta páginas recheadas de tabelas de surpreen- 
dente minúcia a respeito da distribuição do tempo das lições e dos recreios e da dimensão milimétrica da mobília e dos espaços escolares ideais à anatomia e à fisiologia infantis. As longas transcrições das posturas ideais e viciosas dos alunos durante a escrita ilustram bem as proporções delirantes tomadas pelo objetivo de padronização absoluta do ambiente escolar (ibidem, X(IV), p.1-65). Num país em que o suplício comandava o espetáculo da punição física, Rui Barbosa encantou-se com a penalidade incorporal como estratégia política que almejava produzir corpos dóceis por meio de técnicas de quadriculamento do tempo e do espaço em que se encaixariam os indivíduos, tendo em vista fabricá-los como partes submissas e produtivas da engrenagem social.

A ginástica e os exercícios militares são tratados nos pareceres no mesmo tom fanático com que eram prescritos na Europa industrial capitalista. Como modelo, a Alemanha, objeto de irrestrita admiração de Rui como nação que estendeu as raízes da milícia cívica até o ensino popular (ibidem, X(I), p.91). No caso dos meninos, o parecer sobre o ensino secundário e superior prescreve, além da ginástica, tais exercícios, pois, "além do benefício que deles provêm à saúde, ao desenvolvimento do vigor e da destreza, são um precioso elemento de ordem, regularidade e disciplina” (ibidem, p.94). Mais que isso, o manejo de armas nas aulas de educação física recebe forte apoio, porque desenvolve "os elementos morais compendiados na palavra disciplina: atenção forte e viva, obediência pronta, império do indivíduo sobre si mesmo, silêncio, paciência respeito da autoridade" (ibidem, p.95), além de "assentar insensivelmente a base de hábitos morais" (ibidem, p.98-9). Ao destacar o objetivo de construir "insensivelmente" determinados hábitos por meio do treinamento do corpo - ou seja, de implantá-los sem que o educando o perceba -, Rui deixava como herança a contribuição mais poderosa da pedagogia moderna como parte das novas técnicas de controle das condutas.

No Projeto de Reforma do Ensino Primário, o principal argumento a favor da obrigatoriedade ou "coercitividade legal" da educação era seu poder comprovado de reduzir a criminalidade, o que justificava a imposição truculenta, se preciso fosse, da freqüência à escola às crianças do povo. Para que a proposta de pôr a escola na vanguarda da reforma econômica e política tivesse sucesso, impunha-se a obrigatoriedade da freqüência à escola. Para garanti-la, Rui Barbosa não economizou prescrições autoritárias. $\mathrm{Na}$ linha de frente da realização dessa meta estava o controle rigoroso dos dados escolares e a atualização permanente das estatísticas. Muitos foram os profissionais e as instituições sociais convocados a exercer tarefas que garantissem o controle pelos governantes do cumprimento pelos professores e pelo povo da obrigação escolar: juízes, inspetores de quarteirão, párocos, carteiros, jornalistas e educadores. Aos mestres omissos, previu penas crescentes, até a perda do emprego; aos pais resistentes, vários níveis de castigos, até a detenção.

Sob todas essas considerações e prescrições, jazia o preconceito contra o povo brasileiro e a relação persecutória dos ricos com os "de baixo", que 
acreditavam "voltados para o mal”, “portadores de hábitos viciosos”, predispostos ao crime e à loucura. Reforçada por teorias raciais que traziam a marca prestigiosa da ciência, a tradição autoritária que as marcava contaminou de alto a baixo o discurso educacional, quer sobre a educação regular quer no âmbito da reeducação de jovens criminalizados. ${ }^{11}$ A gratuidade do ensino encontrou resistência dos que alegavam que ela transformaria a escola em "escola de indigentes", aumentaria os "perigos da miscigenação de pessoas" e poderia estimular o desinteresse pela escola. A própria co-educação dos sexos, apesar da aura de modernidade, era tratada com desconforto pelos que pensavam a educação no país. Na coleção de fantasmas que assombravam Rui Barbosa, estava o da "mistura social": "não venham gabar-nos os benefícios desse regimen igualista, que pode assentar ombro a ombro, acotovelando-se, o filho grosseiro de uma família qualquer ao pé de uma jovem educada por uma mãe instruída, casta e de grande coração" (Moraes, 1916, p.31), argumento que dava asas ao desejo de apartheid social e escolar.

Em 1889, ao comentar o emperramento da roda da instrução pública durante o século que terminava, Pires de Almeida (1889, p.93-4), depois de arrolar as várias causas que vinham sendo apontadas ao longo do século, responsabilizou o povo, que, "ignorante e bárbaro, não se interessava pela escola". Sob influência das teorias raciais, sentenciou:

nas cidades em geral e no Rio de Janeiro, em particular, há dois elementos presentes: uma classe média inteligente e, em geral, voltada para o bem, e classes inferiores muito miscigenadas, beirando em alguns pontos a classe média, mas quase todas possuindo um fundo hereditário de depravação que transparecerá nas ocasiões de faltas e maus exemplos... As classes ocupadas com trabalhos manuais ou degradadas pelos hábitos ociosos e viciosos parecem, em muitos casos, comprazer-se com a ignorância. As escolas são para os pais desta categoria apenas um meio de ficarem desobrigados da vigilância dos filhos. Já se conhece como são os filhos destes pais: pálidos, fracos, mal-nutridos; trazem em seu rosto um descaramento precoce; instintos perversos já se apropriam do coração destes pequenos seres, que fumam como adultos e não hesitam diante de um copo de pinga.

Convencido de que a ausência da escola deixará espaço ao ensino maléfico da rua e da taverna, Rui Barbosa (1947, X(I), p.163-4) concluiu que

antes assalariar o mestre-escola do que o oficial de polícia; este protege a minha fazenda; o outro ensina a respeitá-la. Previnamos o mal: é melhor do que ter de reprimi-lo. Cada dólar que desembolsamos pela instrução é um prêmio de seguro que pagamos para o tempo vindouro. O Estado, no Brasil, consagra a esse serviço apenas $1,99 \%$ do orçamento geral, enquanto as despesas militares nos devoram $20,86 \%$ da despesa total.

O jogo estava feito, mas a modernização do cotidiano escolar é prescrição que dormirá nos arquivos imperiais, pois o modo de produção e a truculência no exercício do poder dispensavam a escola como formadora de mão-de-obra e como lugar de disciplinamento sutil. No entanto, como parte do projeto de 
Nação da parcela dos proprietários rurais que queriam tirar o país do marasmo monárquico pela assunção da liderança política e que, de fato, dominaram a economia e a política nas décadas seguintes, os pareceres não estavam fora do lugar; ao contrário, voltados para a abolição do trabalho escravo e para o regime republicano, os pareceres somavam com a transição política em curso e serão paradigma das reformas educacionais na Primeira República. Consta que aos vinte anos Lourenço Filho era leitor entusiasmado deles.

\section{Sob o signo de um paradoxo}

No Império, um discurso entusiasmado pela educação escolar convivia com uma rede escolar rarefeita. O descaso pela criação de um sistema escolar assumia duas formas complementares: de um lado, o barateamento aos cofres do Império das despesas com educação; de outro, a substituição da responsabilidade do Estado pela ação de entidades filantrópicas.

A apologia oficial da instrução popular tinha muito de desejo bovarista de parecer europeu. Na prática, a expansão alardeada da rede pública de escolas primárias e profissionalizantes era reduzida à oferta ao povo de rudimentos de leitura e escrita, alguma habilidade manual e muita doutrinação moral e religiosa, tarefa sob medida para instituições filantrópicas religiosas ou leigas. $\mathrm{O}$ próprio método Lancaster de ensino mútuo, no qual alunos ensinavam alunos de modo a atender o maior número possível de educandos com o mínimo de gastos, anunciava essa intenção no advento do Império. Apesar de abandonado por ineficiência nas escolas européias e do resultado quase nulo obtido no Brasil, o ensino mútuo continuou sendo, por mais de vinte anos, a pedagogia oficial das escolas elementares brasileiras. Persistência no erro que "denota o desinteresse e a incompetência com que os responsáveis pela educação no Império cuidavam da educação popular" (Werebe, 1985, p.369-70).

A gestão do ministro João Alfredo foi um marco nesse trajeto, ao mobilizar políticos e ricos para a filantropia educacional. Em 1871, ele criou o Asilo da Infância Abandonada, para acolher crianças órfãs ou miseráveis “por culpa dos pais"; reorganizou o Asilo de Mendicância e fixou, no novo regulamento, a obrigação do mendigo de aprender a ler ou dedicar-se à ocupação útil; articulou a fundação da Associação Municipal Protetora da Infância Abandonada, para dar a crianças pobres meios de aproveitamento do ensino primário, como roupas, calçados e tratamento médico, para o que recebeu apoio de homens de negócios.

Para dar o exemplo, Pedro II fez construir duas escolas em propriedades imperiais: uma, junto ao palácio de São Cristóvão, para filhos de servidores da Casa Imperial; outra, nos domínios do palácio de Santa Cruz, para filhos de antigos escravos da Coroa. Em ambas predominava o ensino profissional, quer em terrenos reservados para práticas agrícolas quer em salas de aulas e oficinas de forja e serralheria, marcenaria e torno, tipografia e litografia, para os meninos, e de corte e costura, bordado, flores artificiais e desenho ornamental, para as meninas. 


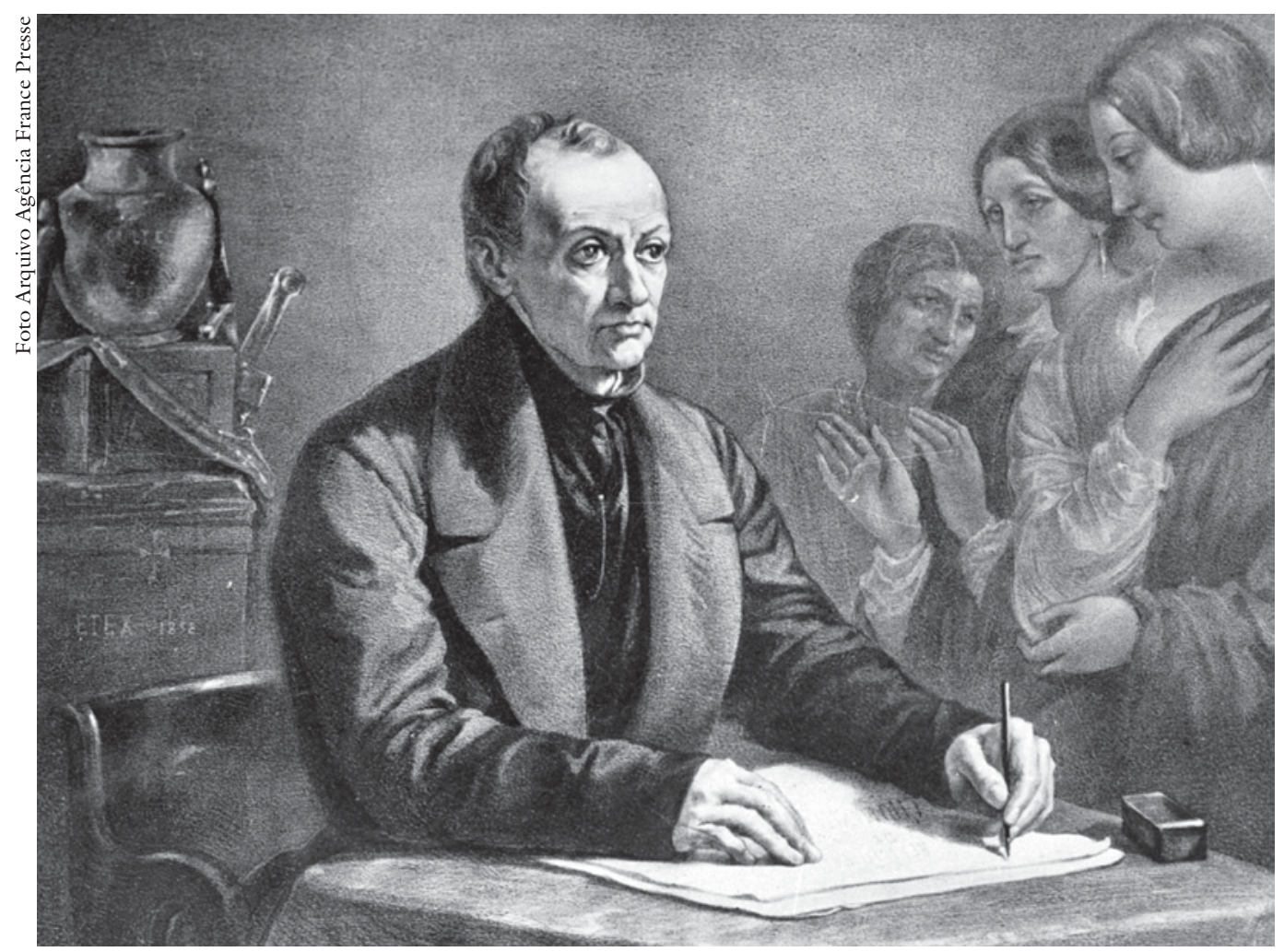

Litografia do filósofo francês Auguste Comte (1798-1875).

Nos últimos quinze anos imperiais, cresceu o número de associações privadas que abriram escolas primárias em vários quarteirões da cidade do Rio, criaram cursos avulsos e, como não podia deixar de ser, asilos para crianças abandonadas. Entre os membros dessas sociedades, não raro havia conselheiros, militares, comendadores, comerciantes, barões, marqueses e viscondes. À medida que novos problemas sociais iam sendo postos pelo fim do trabalho escravo e os proprietários acresciam ao seu rol de preocupações o medo de "caos social", a beneficência alastrou-se, e quase todas as províncias passaram a contar com instituições orfanológicas subvencionadas pelos cofres provinciais ou por doações de beneméritos. Orfanatos, cursos profissionalizantes e pequenas unidades escolares primárias efêmeras eram mantidos pela "generosidade dos particulares" que tentavam ganhar a Corte e o Céu promovendo chás e quermesses para angariar fundos para a criação estabelecimentos de ensino que, em geral, levavam o nome do benfeitor ou de um membro da família, não raro a "veneranda esposa". A instrução popular como favor tornara-se ideologia do Estado, para o que era preciso ignorar a concepção iluminista da educação escolar como direito do cidadão, mesmo que a expressão “difusão das Luzes" fizesse parte dos projetos de reforma escolar desde o Alvará de 1759.

A educação das crianças das classes oprimidas em chave assistencialista atingiu o auge em 1883, com a fundação da Associação Protetora da Infância Desamparada, por iniciativa do marido da princesa, o conde $\mathrm{D}^{\prime} \mathrm{Eu}$, que pôs no 


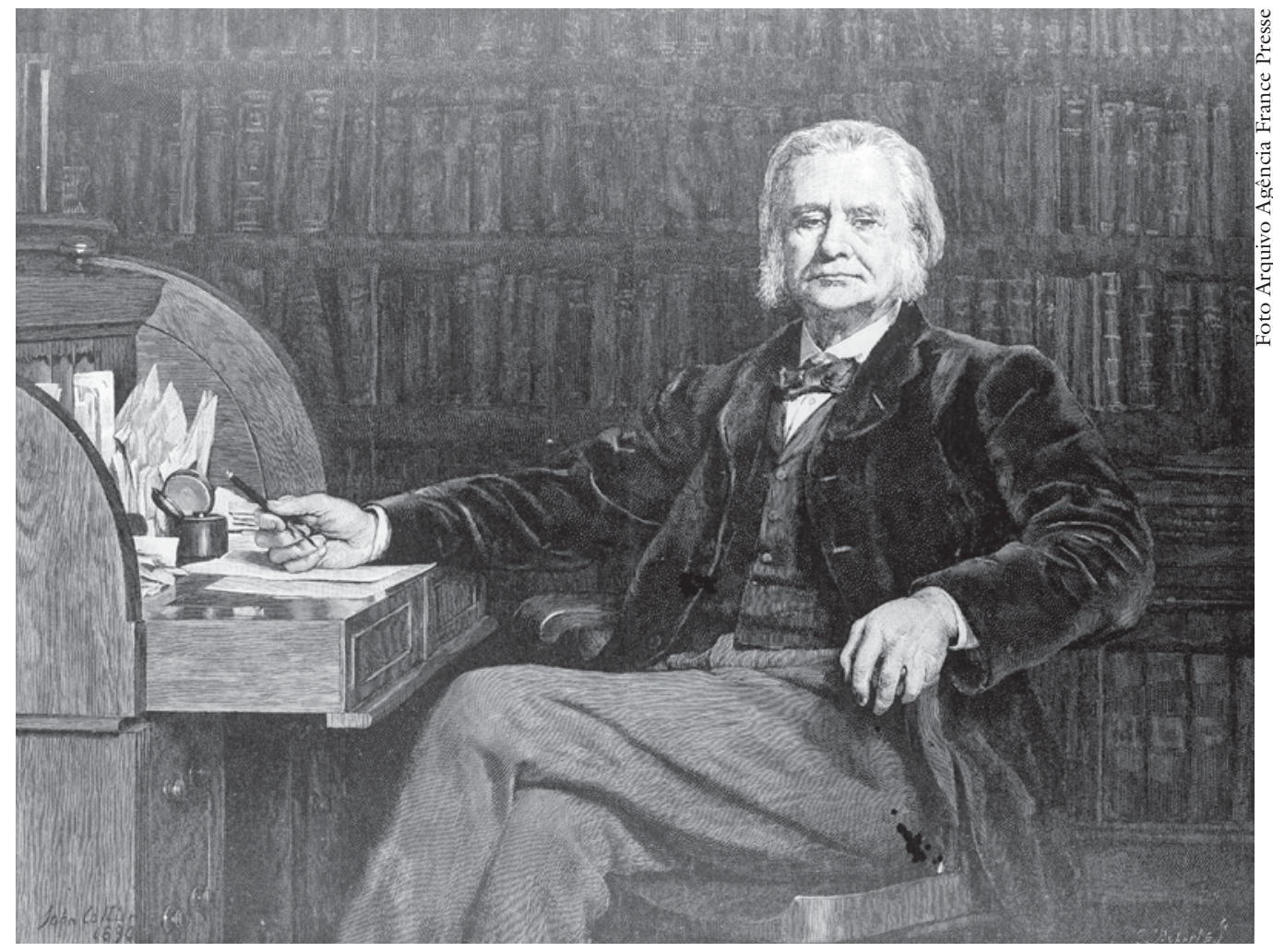

Gravura do filósofo inglês Thomas Henry Huxley (1825-1895).

centro do currículo o ensino agrícola, para "fazer alguma coisa pela moralização da parcela da infância mais desprovida de proteção, dando-lhe hábitos de trabalho e gosto pela agricultura, principal fonte de riqueza do Brasil”. Pela convocação dos filantropos de plantão e mediante um Livro de Caridade, o genro do imperador angariou fundos que lhe permitiram criar mais um asilo: a Colônia Agrícola Santa Isabel, ironicamente próxima à estação do Desengano da Estrada de Ferro Pedro II. Era mais uma instituição nos moldes do Asilo de Meninos Desvalidos, que já funcionava em Vila Isabel; do Instituto Fluminense de Agricultura; do Colégio dos Educandos, no Maranhão; e da Colônia Orfanológica Santa Isabel, em Pernambuco. Os onze primeiros alunos da Colônia Agrícola recém-fundada no subúrbio carioca vieram da Casa de Correção e do Asilo de Mendicantes.

Ao mesmo tempo que o motivo declarado para educar o povo era a formação "de uma inteligência instruída e de uma razão esclarecida” - e assim os nossos eruditos sentiam-se em dia com as Luzes -, falava-se, sem embaraço, em "caridade intelectual" como meio de elevar o nível de moralidade dos pobres. Pelo mesmo motivo, exaltavam-se os asilos para "moças desamparadas", "sementeiras de moças cristãmente educadas", que recebiam "educação prática", nome dado à execução de "todo o serviço interno de vestidos, cozinha, cuidados de limpeza das salas e suas dependências, da capela, lavagem não somente da roupa pessoal, mas também daquela que se recebe de fora, engomagem etc" 
(Pires de Almeida, 1889, p.266), numa “escola" que, na verdade, não passava de instituição de adestramento de futuras empregadas domésticas para as famílias abastadas.

Tudo isso deu continuidade ao processo de construção de um sistema escolar dual que vinha sendo traçado desde o Alvará de 1772, que prescreveu a poucos os "estudos maiores" que "fazem fabricar os homens de Estado", e a “instrução dos párocos” aos "necessariamente empregados nos serviços rústicos e nas artes fabris, que ministram o sustento dos povos e constituem os braços e as mãos do corpo político" (apud Moacyr, 1936, p.22). No fim do período imperial, Rui Barbosa (1947, X(III), p.44) ajudou a pôr essa dualidade na pauta do projeto educacional do país, ao defender a ampliação da escolaridade obrigatória pela criação de réplica da high school norte-americana, que, no entanto, não deveria chegar à altura dos liceus, reservados ao preparo dos filhos dos ricos para a universidade, para as carreiras liberais, para vários ramos de aplicação científica ou industrial do trabalho e para os postos de comando.

Apesar de, ao longo da história econômica e política, a educação escolar aparecer como instituição salvadora em que se depositam esperanças de desenvolvimento econômico e de harmonia social, com ênfase que pode mudar em diferentes períodos, indicadores quantitativos e/ou qualitativos da presença social da escola desmentem invariavelmente as declarações de intenção de políticos e tecnocratas de todos os tempos. No período colonial, faz sentido pensar o desprezo da metrópole pela educação escolar colonial nos mesmos termos em que historiadores entendem o trabalho escravo, ou seja, como parte do projeto da metrópole de não deixar espaço a nenhuma veleidade libertária na colônia (Novais, 1980, p.47-63). A presença da família real não mudou esse cenário. A instrução pública não fazia parte dos planos monárquicos. A criação de instituições culturais no começo do século imperial foi, salvo uma ou outra instituição que formava profissionais para atender às necessidades da Corte, muito mais demonstração de superioridade dos nobres portugueses do que interesse pelo Brasil. Ao longo dos quase setenta anos imperiais, foram muitos os discursos e debates parlamentares e os projetos de reforma da educação escolar, todos eles pautados pelos princípios educativos em voga na cena européia e norte-americana e compostos de doses generosas de admiração pela Europa próspera, de descompasso entre o dito e o feito e, não raro, de arrematado ridículo. No Império, um país exportador de matéria-prima tropical extraída por trabalhadores escravizados não carecia de um sistema de ensino público eficiente como instrumento de formação de mão-de-obra, fosse ela técnica ou intelectual, e, muito menos, como meio sofisticado de garantir obediência.

No Primeiro Império quase nada se fez no plano da instrução pública, fato coerente com o absoluto desprezo de governantes portugueses e brasileiros, liberais ou não, pela cidadania. A Carta Constitucional por ele outorgada depois de dissolver a Constituinte continha um liberalismo de fachada, do qual fazia parte referência vaga à criação de escolas em todas as províncias. Um decreto de 1829, 
que criava uma comissão encarregada de elaborar um projeto de regulamentação das escolas primárias, resultou em nada: "desgraçadamente, como é ainda freqüente entre nós, depois do decreto não se ouviu mais falar da comissão". No mesmo período, leis e resoluções sobre a instrução secundária "encontraram muitas dificuldades em sua aplicação” (Pires de Almeida, 1889, p.61).

O Ato Adicional de 1834 veio para conciliar as três forças políticas em confronto: a preservação da condição vitalícia dos senadores foi concessão aos restauradores; a autonomia das províncias, pela criação de assembléias legislativas provinciais, contemplou os liberais radicais; a abolição do Conselho de Estado e a transformação da Regência Trina em Regência Una satisfizeram o anseio de centralização política dos liberais moderados. Ao delegar a educação escolar às assembléias provinciais, transformando-a em peça de um jogo político que queria sossegar o separatismo das províncias do norte e calar os clamores de liberais radicais em torno dos direitos do homem e do cidadão, os articuladores da reforma constitucional entregaram a educação escolar fundamental, sem nenhuma diretriz, a administrações sem recursos técnicos, humanos e financeiros, deixando-a à mercê de latifundiários que não tinham nenhum interesse em escolarizar o povo.

O resultado foi uma profusão de leis provinciais sem condição de vigência: "criaram-se muitas escolas - no papel” (ibidem, p.65). A referência à escola como instituição de formação intelectual era sistematicamente omitida; quando mencionada, era para repudiá-la; nessa direção, a objeção de um parlamentar a uma proposta do Conselho Geral da Província de São Paulo de criação de um Curso de Ciências Sociais, de 1834, é reveladora dos critérios que alicerçavam a política de ensino: "é pernicioso estimular os homens para estes conhecimentos sociais, porque neste estado ficam mais aptos para promover rusgas" (Moacyr, 1936, p.231-2ss). Na penumbra da sala do Conselho, a proposta não foi aceita. Em 1836, relatório do Ministério do Império não conseguia esconder: “o estado das escolas é deplorável" (Pires de Almeida, 1889, p.61).

A disputa política que criou os partidos Liberal e Conservador absorveu parlamentares e a educação escolar continuou fora de foco. Relatórios sobre a situação do ensino e propostas de reforma da educação escolar entre 1849 e 1879 falavam da mesma coisa: foi assim com o relatório do poeta Gonçalves Dias sobre as províncias do Norte do Brasil, datado de 1849, falava em insuficiência das matérias ensinadas; má escolha dos livros didáticos; programas mal organizados; falta de inspeção; freqüência irregular; má qualificação dos mestres (ibidem, p.86-7). Foi assim com as reformas de base propostas em 1869 pelo Conselheiro Paulino, em nome das Luzes, mas que se limitaram a uma ou outra reforma de prédios escolares, à doação de alguma verba a algumas das poucas instituições culturais e a um plano de adaptação dos edifícios escolares segundo os princípios da Higiene. Foi assim com o ministro João Alfredo, sucessor de Paulino, que em meio a prescrições para o aprimoramento da educação escolar tomou como medida mais concreta de sua gestão a compra, com verba pública, 
de duas esculturas de um obscuro artista fluminense: Crime, instalada na Casa de Correção, e Gênio acorrentado pela miséria, posta em lugar de destaque no Asilo de Mendicância (ibidem, p.143).

Relatório de inspetor do ensino secundário, em meados do século, dizia da lamentável formação dos alunos: "a maioria [...] ignorava os mais elementares princípios da Gramática da língua nacional e não sabia responder às mais simples questões de seus examinadores. As composições escritas de quase todos eles apresentavam uma reunião de palavras sem nenhum sentido, frases sem ligação e sem significação" (ibidem, p.88). A situação era tal que, no fim do período imperial, até mesmo monarquistas, como o historiador Pires de Almeida, desanimavam:

em matéria de instrução primária e também instrução secundária no Rio de Janeiro, é grande a distância entre a aparência e a realidade. Cresceu o número de alunos: isto não significa que a cultura dos espíritos tenha aumentado [...] Há de fato muitas crianças, meninos e meninas, de doze anos e mais, que freqüentam as escolas primárias públicas e são incapazes de escrever por eles mesmos o que quer que seja; sabem apenas contar ou sabem apenas ler. (ibidem, p.89)

Atento à expansão e às características dos sistemas públicos de ensino na Europa e nos Estados Unidos, Rui Barbosa (1947, X(I), p.17) deplorava, com razão, a realidade educacional brasileira e concluiu que, a continuar no ritmo indolente da matrícula observado entre 1857 e 1878, seriam necessários 799 anos para fazer chegar a toda a população em idade escolar a instrução primária no país. Impressiona-o particularmente o número de analfabetos. A comparação com outros países deixa-o desolado e irritado com o otimismo impostor de algumas autoridades e leva-o a concluir que "há sobeja matéria para nos enchermos de vergonha" (ibidem, p.8). Quanto à qualidade do ensino oferecido, denunciou a "ausência absoluta de método e racionalidade", a rudimentaridade do material pedagógico e o despreparo desconcertante do corpo docente, produto de Escolas Normais que, na capital do Império, não passam de "simples mecanismo de diplomar a incapacidade" (ibidem, p.82). Tudo isso leva-o a concluir que o ensino escolar brasileiro é "perfeita humilhação nacional” (ibidem, p.31).

Documentos oficiais falavam de marcha lentíssima, quando não de estagnação ou mesmo de retrocesso na construção de um sistema de instrução pública. Em 1886, a Comissão encarregada pelo barão de Mamoré, então ministro do Império, de estudar as bases para a reorganização do ensino primário e secundário no Município Neutro, relatou:

a instrução em todos os seus graus está em sensível decadência. O ensino superior apresenta os mais deploráveis sintomas. $\mathrm{O}$ secundário, quase exclusivamente a cargo de iniciativas particulares tem degenerado em simples meio de chegar às escolas superiores, dali resultando o desleixo com que a maior parte dos estabelecimentos e deste ramo de ensino, depondo os escrúpulos de uma missão conscienciosa, qual deverá ser a sua, buscam em outros alvitres os meios 
de auferir maiores lucros. O ensino primário, apesar dos grandes esforços que em prol dele hão sido envidados, é quase nulo em seus benéficos efeitos; poucas escolas, freqüência insignificante, mestres mal preparados.

O resultado é uma conclusão melancólica: "É este o quadro triste e sombrio do ensino entre nós” (Moacyr, 1936, v.2 , p.444). Num campo escolar minguado de uma sociedade agrária que dispensava qualquer iniciativa consistente de educação pública, o parecer de Rui Barbosa era proposta pedagógica que não podia vingar. Inviável naquele momento do país, ela não teve andamento na Câmara e "passou ao mofo e traçaria dos arquivos", apesar do interesse despertado, inclusive no imperador, que, munido de um exemplar cuidadosamente anotado, convidou o autor a um tête-à-tête no palácio, para discutirem os pareceres.

Refletindo sobre o que a história tem a dizer-nos sobre a sociedade contemporânea, Hobsbawm (1998a, p.47) faz três afirmações sobre a história como unidade de passado, presente e futuro que são essenciais à reflexão sobre o discurso educacional brasileiro na atualidade: primeira, "a maior parte do que a história pode nos dizer sobre as sociedades contemporâneas baseia-se em uma combinação entre experiência histórica e perspectiva histórica"; segunda, "o que ela não pode nos dizer é o que acontecerá: apenas quais os problemas que teremos que resolver"; terceira, "infelizmente uma coisa que a experiência histórica também ensinou aos historiadores é que ninguém jamais parece aprender com ela". Um dos problemas fundamentais do que se espera da educação escolar hoje é a surdez à experiência histórica, que resulta na repetição de bordões que já se mostraram equivocados. Nesse aspecto, estamos em situação pior do que os planejadores da educação no Império, que pelo menos tinham a seu favor os fatos de que não podiam se valer da experiência histórica acumulada em se tratando de política educacional e não estavam numa república com veleidades democráticas.

A respeito da dispensabilidade de um sistema escolar eficiente como instrumento de controle social pela doutrinação ideológica numa sociedade escravocrata, não é demais lembrar duas frases que já mencionamos em outro lugar a respeito da ausência da escola e da presença de práticas de violência física no período escravocrata: "quando regem relações imediatas de poder, não existem ideologias, num sentido estrito” (Horkheimer \& Adorno, 1973, p.191), ou seja, onde vigora a força bruta, torna-se dispensável "a sutileza do cimento ideológico menos rasteiro" (Arantes, 1988, p.186).

O panorama atual da sociedade brasileira, embora não mais pautado pelo modo de produção escravista, nos põe, no entanto, diante da seguinte questão: até que ponto o Estado, num país que faz parte da lógica da globalização, que dispensa cada vez mais o trabalho de grandes contingentes de trabalhadores, e que está entre os campeões mundiais de desrespeito bárbaro aos direitos humanos, vê-se de fato diante da premência de investir num sistema de instrução 
pública que garanta a todos a posse de habilidades e conhecimentos a que têm direito como participantes de uma sociedade em que predominam o letramento e a informação técnico-científica e que os domestique por meio de uma visão ideológica de mundo?

Para responder a essa pergunta não se podem esquecer duas características da relação de classes que atravessam a história do país como formas poderosas de dominação: de um lado, o clientelismo, que transforma direitos em favores dos poderosos e põe as ações em chave assistencialista; de outro, a violência física, potenciada em momentos de conflito social pelo investimento nas instituições policiais. ${ }^{12} \mathrm{O}$ que acontece hoje? Fala-se o tempo todo em investir em educação, mas o que se vê é o aumento da presença da polícia, da matança indiscriminada dos pobres a céu aberto e a pressão social por medidas rápidas no âmbito jurídico-policial. O que significa que não se pode entender o descaso pela escola como aparelho ideológico se não se levar em conta a presença do aparato repressivo quando se trata de conter a revolta dos segmentos de classe mais expropriados de seus direitos como cidadãos. Nesse terreno, a reivindicação de uma escola voltada para a formação do pensamento, em seu sentido pleno de reflexão e crítica, para além da razão meramente instrumental, não tem nenhuma chance, a não ser como postura política de insistência na recusa do estabelecido.

Como é possível perceber, são muitos os problemas que teremos de enfrentar. Menciono alguns, sem nenhuma intenção de esgotar o assunto, muito menos de oferecer receitas. É preciso resgatar a escola como instituição de ensino de capacidades e informações que, na modernidade, cabe a ela oferecer, como garantia do direito do cidadão ao letramento e ao saber; para isso, é necessário pôr em primeiro plano a revalorização dos educadores em três frentes: salário, formação e participação nas decisões que afetarão o seu fazer profissional. É urgente a mudança radical das instituições de detenção de menores, eufemisticamente chamadas de "socioeducativas", para que deixem de ser espaços de barbárie e se transformem em lugares de escuta da dor da humilhação como sofrimento político (pois engendrado em relações desiguais de poder), para que seus portadores possam apropriar-se dela no plano simbólico, única forma de superar a retaliação cega e muitas vezes fria que essa dor engendra e de tornála alavanca de entendimento, por parte desses jovens, da lógica que move uma realidade social que violenta o tempo todo os despossuídos e de ações que contribuam para a transformação dela em direções de fato democráticas. ${ }^{13}$

É imprescindível a escolha de ministros e secretários de Educação que tenham formação intelectual compatível com o cargo e que se cerquem de assessores que não sejam carreiristas e que não eternizem equívocos grosseiros, como querer construir um outro edifício educacional começando pelo telhado (a elaboração de novo currículo, por exemplo), entender a escola como instituição preventiva do crime, fazer recomendações pedagógicas nos termos de livros de auto-ajuda ou justificar a perda de qualidade do ensino como conseqüência 
inevitável da expansão quantitativa da rede escolar, como se não se soubesse há décadas que quantidade e qualidade não são incompatíveis em se tratando de política educacional. ${ }^{14}$ Acima de tudo, cumpre livrar a política educacional dos interesses político-partidários que fazem dela moeda eleitoral e causam-lhe danos cuja gravidade, em toda a sua extensão e profundidade, começa a revelar-se nua e crua.

Sem isso, e sem muitas outras medidas, continuaremos presas do poder do atraso num país em que "a tradição dos oprimidos nos ensina que o estado de exceção em que vivemos é na verdade regra geral" e que, por isso, "precisamos construir um conceito de história que corresponda a essa verdade. Nesse momento, perceberemos que nossa tarefa é criar um verdadeiro estado de emergência” (Benjamin, 1994).

\section{Notas}

1 Este texto foi elaborado a partir do segundo capítulo - "Um quadro triste e sombrio: notas sobre o projeto educacional no Segundo Império" - do livro de minha autoria, A fiscalização dos pobres: ciência e política na Primeira República, cujos originais encontram-se em fase de finalização. "Escolas cheias, cadeias vazias": Frase muito citada durante a segunda metade do século XIX por vários intelectuais europeus, entre eles o escritor francês Victor Hugo, a quem alguns historiadores do período atribuem a autoria.

2 Ver, por exemplo, Frigotto (2001).

3 Para um retrato sem retoque da presença do assistencialismo no cenário educacional brasileiro atual, ver Passetti (1999, p.347-75). Sobre o conceito de inclusão marginal, ver Martins (1997, em especial o capítulo 1).

4 Note-se que o próprio conceito de prevenção é polêmico. Ver Freire Costa (1989, p.21-38).

5 Sobre a violência em escolas públicas brasileiras, ver "Os jovens, a escola e os direitos humanos" (2000).

6 Sobre o engajamento político do cientista, em geral, e do historiador, em particular, ver Hobsbawm (1998b, p.138-54).

7 Transcrito em Moacyr (1936, p.13-6).

8 Mais de meio século depois de Rui Barbosa, Lourenço Filho (1940), fiel a essa idéia, porá, em plena ditadura Vargas e falando sobre segurança nacional na Escola do Estado-Maior do Exército, a escola entre as instituições de "segurança por antecipação", que é como ele nomeia as instituições de prevenção da "desordem social".

9 Em 1882, a Typographia Nacional imprimiu o Parecer sobre a Reforma do Ensino Secundário e Superior e, em 1883, o Parecer sobre a Reforma do Ensino Primário, incluídos nos Anais do Parlamento Brasileiro. Esses Pareceres fazem parte das Obras completas de Rui Barbosa, mandadas publicar, sob os auspícios do governo federal, pelo ministro Gustavo Capanema, em 1941, cujo primeiro volume, publicado em 1942, reuniu os pareceres. A coleção completa foi impressa por decreto do presidente Eurico Gaspar Dutra e publicada pelo Ministério da Educação e Saúde, em 1947. O parecer sobre o ensino secundário e superior encontra-se no v.IX, tomo I; o que se refere ao ensino primário, no v.X, tomos I, II, III, IV. 
10 Em Lourenço Filho (s. d.), encontra-se uma análise detalhada da estrutura e do conteúdo dos pareceres.

11 Na Primeira República, essa concepção sobre as crianças e os jovens das classes populares e das medidas reeducativas necessárias atingiu expressão perfeita no livro do jurista Evaristo de Moraes (1916).

12 Sobre a ampliação da força policial no Segundo Império, ver Castro (1985). Sobre as medidas tomadas na Primeira República, ver Fernandes (1985).

13 Sobre a humilhação como sofrimento político, ver Gonçalves Filho (1998).

14 Desde os anos 1960, o campo educacional conta com estudos sobre essa questão. Ver Beisiegel (2006).

Referências bibliográficas

ADORNO, T. W. Educação e emancipação. Rio de Janeiro: Paz e Terra, 1995.

ARANTES, P. O positivismo no Brasil. Novos Estudos Cebrap, n.21, p.186, jul. 1988.

BARBOSA, R. Reforma do Ensino Primário. In: Obras Completas de Rui Barbosa. Rio de Janeiro: Ministério da Educação e Saúde, 1947. v. X.

BEISIEGEL, C. R. A qualidade do ensino na escola pública. Brasília: Liber Livro, 2006.

BENJAMIN, W. Sobre o conceito de história. In: _. Magia e técnica, arte e politica. São Paulo: Brasiliense, 1994. v.1: "Obras Escolhidas", p.226.

BOSI, A. Educação: as pessoas e as coisas. Jornal do Brasil, Rio de Janeiro, 10.2.1996.

BUARQUE DE HOLANDA, S. Raizes do Brasil. 15.ed. Rio de Janeiro: José Olympio, 1982.

CASTRO, J. B. de. A Guarda Nacional. In: BUARQUE DE HOLANDA, S. (Org.) História geral da civilização brasileira. 4.ed. São Paulo: Difel, 1985. t.II, v.4: "O Brasil monárquico", p.274-98.

FERNANDES, H. R. A Força Pública do Estado de São Paulo. In: FAUSTO, B. (Org.) História geral da civilização brasileira. 3.ed. São Paulo: Difel, 1985. t.III, v.2: “O Brasil republicano", p.235-56.

FREIRE COSTA, J. História da psiquiatria no Brasil. Rio de Janeiro: Xenon, 1989.

FRIGOTTO, G. A produtividade da escola improdutiva. 6.ed. São Paulo: Cortez, 2001.

GONÇALVES FILHO, J. M. Humilhação social: um problema político em Psicologia. Psicologia USP, v.9, n.2, p.11-67, 1998.

HELLER, A. O cotidiano e a história. Rio de Janeiro: Paz e Terra, 1972.

HOBSBAWM, E. O que a história tem a dizer-nos sobre a sociedade contemporânea? In: _. Sobre História. São Paulo: Cia. das Letras, 1998a.

p.138-54.

Engajamento. In: . Sobre História. São Paulo: Cia. das Letras, 1998b.

HORKHEIMER, M.; ADORNO, T. W. Temas básicos de sociologia. São Paulo: Cultrix, 1973. 
LOURENÇO FILHO, M. B. A Pedagogia de Rui Barbosa. São Paulo: Melhoramentos, s. d. LOURENÇO FILHO, M. B. Educação e segurança nacional. In: Tendências da educação brasileira. São Paulo: Melhoramentos, 1940.

MARTINS, J. de S. Exclusão social e a nova desigualdade. São Paulo: Paulus, 1997. O poder do atraso. Ensaios de sociologia da história lenta. 2.ed. São Paulo: Hucitec, 1999.

MAXWELL, K. Marquês de Pombal-Paradoxo do Iluminismo. Rio de Janeiro, Paz e Terra, 1996.

MOACYR, P. A instrução no Império. São Paulo: Nacional, 1936. v.1.

MORAES, E. de. Criminalidade da infancia e da adolescencia. Rio de Janeiro: Francisco Alves, 1916.

NOVAIS, F. O Brasil nos quadros do antigo sistema colonial. In: MOTA, C. G. (Org.) Brasil em perspectiva. 11.ed. São Paulo: Difel, 1980. p.47-63.

OS JOVENS, A ESCOLA E OS DIREITOS HUMANOS. Relatório de Cidadania II, Rede de Observatórios de Direitos Humanos. São Paulo: ONU/NEV-USP, 2000, Capítulo "Escola e violência", p.37-73.

PASSETTI, E. Crianças carentes e políticas públicas. In: DEL PRIORI, M. (Org.) História das crianças no Brasil. São Paulo: Contexto, 1999. p.347-75.

PATTO, M. H. S. Teoremas e cataplasmas no Brasil monárquico. Novos Estudos Cebrap, n.44, p.180-99, mar. 1996.

Estado, ciência e polícia na Primeira República: a desqualificação dos pobres. Estudos Avançados IEA-USP, v.13, n.35, p.167-98, jan.-abr. 1999.

PIRES DE ALMEIDA, J. R. Histoire de l'Instruction Publique au Brésil (1500-1889). Histoire et Legislation. Rio de Janeiro: Leuzinger Ed., 1889.

. Instrução pública no Brasil (1500-1889). História e Legislação. São Paulo: Inep, PUC-SP, 1989.

SCHWACZ, L. M. O espetáculo das raças. Cientistas, instituições e questão racial no Brasil. 1870-1930. São Paulo: Cia. das Letras, 1993.

WEREBE, M. J. G. A educação. In: BUARQUE DE HOLANDA, S. (Org.) História geral da civilização brasileira. São Paulo: Difel, 1985. v.6, p.369-70.

RESUMO - Sobre o pano de fundo do desemprego, da violência e da precariedade do ensino público fundamental e médio brasileiros atuais, vem ganhando força um discurso que atribui à escola a missão social de prevenção da criminalidade juvenil, não pelo ensino de conteúdos e habilidades ou de preparação para o trabalho, mas como espaço de permanência dos alunos que supostamente os protege dos "caminhos da criminalidade". Uma pesquisa documental - com destaque para os pareceres de Rui Barbosa sobre a educação nacional, datados de 1882-1883, mas voltados para o projeto republicano que estava em andamento - revela, no entanto, que o lema "escolas cheias, cadeia vazias" é antigo no discurso educacional do país e data da passagem do Império à República e de suas conseqüências sobre a vida nas cidades: a chamada "questão social" da Primeira República, tida por alguns como "caso de polícia", e por outros como "caso 
de educação". Embora ciente de que a história é também descontinuidade, a análise destaca a continuidade do processo histórico brasileiro, na qual idéias e ações oficiais, aparentemente diversas, repõem-no sob novas vestes. O texto termina apontando algumas medidas que se fazem necessárias e urgentes se não quisermos permanecer reféns do poder do atraso inerente à lentidão da história do Brasil.

PALAVRAS-CHAVE: Política educacional brasileira, História da educação, Educação e ideologia.

ABSTRACT - In the current background of unemployment, violence and precariousness of Brazilian secondary education system, a new discourse has been gaining strength. According to this discourse, the school has the social mission of preventing juvenile criminality. This is not expected to be done by teaching content and skills or by preparing for the job market, but by being a hangout area where students are protected from the "criminal paths". A documentary survey - highlighting Rui Barbosa's judgments about national education, which date from 1882-1883 and are centered on the republican project that was taking place - reveals, however, that the motto "full schools, empty jails" is an old one in the educational discourse of the country. It dates from the transition from Empire to Republic and from its consequences on the lives of the cities: the so-called "social issue" of the First Republic, considered by some a "police matter" and by others an "education matter". In spite of our awareness that history is also discontinuity, the analysis will emphasize the continuity of Brazilian historical process, in which ideas and official action - apparently dissimilar - display the same core in different outerwear. In the end of the article, we indicate necessary and urgent measures to be taken if we are not to be held as hostages of the loitering power that is inherent in Brazilian history.

KEYWORDS: Brazilian education policy, History of education, Education and ideology.

Maria Helena Souza Patto é professora do Instituto de Psicologia da Universidade de São Paulo. @ - mhspatto@usp.br

Recebido em 24.11.2006 e aceito em 9.5.2007. 